\title{
A mixed data sampling approach to the asymmetric impacts of world oil price on macroeconomic variables in Vietnam
}

\author{
Trinh Thi Tuyet Pham and Nhan Phan Ai Le \\ International Economics Faculty, Banking University of Ho Chi Minh City, \\ Ho Chi Minh, Vietnam
}

\begin{abstract}
Purpose - This paper aims to analyse the asymmetric impacts of world oil price on macroeconomic variables in Vietnam, including domestic oil price, inflation and output growth.

Design/methodology/approach - The mixed data sampling (MIDAS) approach is employed to examine the impact of world oil price changes on macroeconomic variables as the former is high-frequency data (daily), and the latter is low-frequency data, usually monthly or quarterly.

Findings - Changes in world oil price cause asymmetric impacts on domestic oil price and inflation, but no significant effects on output growth. In terms of magnitude, a positive change in world oil price causes a stronger effect than a negative change in world oil price. In terms of timing, a positive change in world oil price causes a slow pass-through impact on domestic oil price and inflation. Meanwhile, domestic oil price and inflation decrease quickly following a negative change in world oil price.

Originality/value - This study investigates the asymmetric impact of oil price on the Vietnam economy in terms of both magnitude and timing, which is not explored by previous studies. In addition, it exploits daily information of oil price changes to analyse macroeconomic variables in lower frequency by employing MIDAS approach.
\end{abstract}

Keywords Asymmetric impact, Inflation, MIDAS, Oil price, Output growth

Paper type Research paper

\section{Introduction}

As oil and petroleum products are necessary input of production processes, the fluctuation of oil price causes a widespread impact on activities of the real economy. In theory, an increase in oil price could push up cost production (Rasche and Tatom, 1981; Barro, 1984; Brown and Yücel, 1999), deteriorate disposable income (Bernanke, 1983; Pindyck, 1991), raise insurance saving (Başkaya et al., 2013), postpone consumption on durable goods related to oil (Kilian, 2009) and curb investment (Başkaya et al., 2013). These impacts lead to a reduction of aggregate demand and a decline in output as a result. As the response of aggregate demand is lagged, inflation pressure also increases following an oil price rise (Ebrahim et al., 2014). In reverse, if there is a downward change in oil price, output will increase, and aggregate price will decrease. However, the impacts of positive and negative changes in oil price on output and aggregate price could be asymmetric because of different expectations from the market.

\section{JEL Classification - C32, F41, Q43}

(C) Trinh Thi Tuyet Pham and Nhan Phan Ai Le. Published in Journal of Economics and Development Published by Emerald Publishing Limited. This article is published under the Creative Commons Attribution (CCBY 4.0) license. Anyone may reproduce, distribute, translate and create derivative works of this article (for both commercial and non-commercial purposes), subject to full attribution to the original publication and authors. The full terms of this license may be seen at http://creativecommons. org/licences/by/4.0/legalcode 
JED

22,2

312

In other words, responses of the economy to the increase and decrease in oil price could not be the same in magnitude and timing.

There are various studies evidencing significant impact of oil price fluctuations on real economy (see Rasche and Tatom, 1981; Darby, 1982; Hamilton, 1983; Burbidge and Harrison, 1984; Gisser and Goodwin, 1986). Studies in the early stages usually assume linear relationship between oil price and real output. However, the fact that sharp declines in oil price in 1980s caused negligible impact on the economy posed question about the significance of the linear basis. Therefore, the asymmetric nature of oil price impact has been discovered by various studies since the mid-1980s (see Mork, 1989; Lee et al., 1995; Hamilton, 1996; Valcarcel and Wohar, 2013; Luiggi and Neil, 2016; Long and Liang, 2018). For the case of Vietnam, Trung and Vinh (2011), Trang and Hong (2016) also indicate a significant impact of oil price on the economy by using VAR methodology and threshold regression respectively. This study follows this strand of research with two contributions. First, the study exploits daily information of oil price changes to analyse macroeconomic variables in lower frequency by employing mixed data sampling approach (MIDAS). Second, the study investigates the asymmetric impact of oil price on the Vietnam economy in terms of both magnitude and timing, which is not explored by previous studies.

\section{Literature review}

\subsection{Impacts of oil price on the economy}

The impact of world oil price fluctuations on domestic macroeconomic variables can be analysed through the aggregate supply-aggregate demand model.

On the aggregate supply side, as oil products are essential input for the production process, a positive oil price shock pushes up the production costs of enterprises, resulting in a decrease in aggregate supply (Rasche and Tatom, 1981; Barro, 1984; Brown and Yücel, 1999). On the aggregate demand side, consumption and investment are negatively affected by a positive oil price shock. The shrinkage of consumption is derived by the reduction in disposable income as consumers have less money to spend after paying gasoline-related bills (Bernanke, 1983; Pindyck, 1991). Unexpected fluctuations in oil price also cause precautionary savings to increase and consumption to decrease as consumers worry about potential unemployment or income drop in the future (Başkaya et al., 2013). In addition, consumers tend to postpone spending on durable goods when petroleum prices rise (Kilian, 2009). From investors' perspectives, when detrimental impacts of oil price fluctuations on production costs as well as consumer demand threatens the profitability of new projects, investments will be postponed or even eliminated (Başkaya et al., 2013).

To sum up, a positive oil price shock leads to a decline in aggregate supply and aggregate demand, resulting in a decrease in output. Meanwhile, the impact of this shock on inflation is unclear. The decline in aggregate supply causes pressure on inflation, but the reduction in aggregate demand causes pressure on deflation. Ebrahim et al. (2014) argued that inflationary pressure seems to outperform the pressure of deflation in the short term because consumers do not adjust their spending immediately in the context of oil price shock.

\subsection{Asymmetric impacts of oil price on the economy}

In the early stages of this research topic, most empirical studies indicate a negative linear relationship between oil price and real output (Rasche and Tatom, 1981; Darby, 1982; Hamilton, 1983; Burbidge and Harrison, 1984; Gisser and Goodwin, 1986). However, since the mid-1980s, such linear relationship has lost significance. Actually, the sharp decline in oil price in the 1980s was found to have smaller positive impact on the economy than predicted by linear models. Therefore, Mork (1989), Lee et al. (1995), Hamilton (1996) began to study the 
non-linear relationship between these two variables. These studies showed that there is an asymmetry when comparing the reaction of output to an increase in oil price shock with that to a decrease in oil price shock: the magnitude of output reduction due to positive oil price changes is larger than the magnitude of output increase due to negative oil price changes. This phenomenon can be explained by three main reasons.

The impact of uncertainty is one of the reasons. Oil price shocks are correlated with expectations for more volatility of oil price in the future. Under such uncertainty, consumers and investors will cut spending, leading to decline in output. This effect may amplify the impact of oil price increase and offset the impact of oil price decline.

The second reason is the reallocation effect. Oil price volatility leads to reallocation of production factors such as labour and capital from shrinking sectors to expanding sectors (Davies, 1987; Bresnahan and Ramey, 1993; Davies and Haltiwanger, 2001). For example, when high oil price diminishes the demand for cars, labour and capital from the car industry will be reallocated to other industries or reallocated to the industries producing energyefficient vehicles. Reallocation is costly, on the other hand. As some production factors are industry-specific, they cannot be easily converted to new uses, resulting in declining output and increasing unemployment. Hamilton (1988) argued that similar results could also occur if some unemployed workers decide not to move to another industry in the hope that their sector will improve after the oil price shock. Thus, in the case of an increase in oil price, the reallocation effect combined with a decline in aggregate demand makes output plummet. Meanwhile, if oil price falls, the reallocation effect will offset the rise in aggregate demand, causing a smaller increase in output than implied by a linear model.

In addition, Bernanke et al. (1997) argued about the reaction of monetary policy. When oil price rises, the central bank tightens monetary policy to cope with the risk of inflation. The economy falls into a more severe recession as a result. In contrast, when oil price falls, relatively strong policy response does not happen.

Similarly, empirical studies on the impact of oil price on inflation also show the asymmetry (see Mork, 1989; Hamilton, 2009; Valcarcel and Wohar, 2013; Luiggi and Neil, 2016; Long and Liang, 2018). Long and Liang (2018) proved when oil price rises, inflation increases very quickly, but when oil price falls, inflation does not necessarily reduce. Meanwhile, Luiggi and Neil (2016) showed the impact of negative oil price shock on inflation is stronger than that of positive oil price shock. To explain this asymmetric phenomenon, such studies focus on some of the following main points:

Firstly, the market power. When world crude oil price rises, the import costs of domestic petroleum companies will increase. To ensure profitability, these companies will quickly adjust their selling prices. However, when world oil price falls, these companies will have no incentive to reduce selling prices. They can do this thanks to the monopoly power in the market. For example, China's oil market is oligopoly and activities including production, import and wholesale of oil are mainly controlled by three companies. Long and Liang (2018) argued that such non-competitive market structure caused asymmetric transmission of crude oil price to production price index (PPI) and consumer price index (CPI) in China.

Second, the adjustment cost. The cost of domestic price adjustment relative to world price increases the cost of producers. This effect may reinforce the impact of a positive oil price shock and offset the impact of a negative oil price shock on the aggregate supply.

Third, the government's intervention. Price control measures, such as ceiling price, create a specific limit on a price adjustment. The reaction of monetary policy (as discussed above) is another explanation of asymmetric effects.

For the case of Vietnam, Thanh et al. (2009) used an input-output model to demonstrate that in the scenario of a $30 \%$ increase in gasoline price, GDP would decrease $0.4 \%$, PPI would increase $2.56 \%$, CPI would increase $3.67 \%$. Using the VAR model and the case of Vietnam in 1995-2009, Trung and Vinh (2011) showed the long-run relationship between world oil price 
JED

22,2

314

and domestic industrial production. When world oil price increases (or decreases) by $10 \%$, the index of industrial production will increase (or decrease) by $1.81 \%$. Trang and Hong (2016) also studied the impact of oil price on Vietnam's macroeconomic variables in the period 20002015 by using the TVAR model. The study indicated the oil price threshold of 26.7 USD/ barrel. If oil price is above this level, an increase in oil price will cause an increase in the inflation rate, unemployment rate and budget deficit, while the reaction of GDP to the shock of oil price is not statistically significant.

\section{Research methodology}

\subsection{Research model and estimation method}

The study employs MIDAS approach to examine the impact of world oil price changes on macroeconomic variables as the former is high-frequency data (daily), and the latter is lowfrequency data, usually monthly or quarterly. The usage of this approach allows us to exploit daily information of oil price to analyse macroeconomic variables in Vietnam. On the lefthand side of the model (1), $Y_{t}$ is representative of macroeconomic variables which are regressed respectively on world oil price $\mathrm{OP}_{t} . Y_{t}$ includes domestic oil price $\left(\mathrm{VOP}_{t}\right)$ and inflation $\left(\mathrm{INF}_{t}\right)$ in monthly frequency, output growth $\left(\mathrm{GDP}_{t}\right)$ in quarterly frequency. The right-hand side of the model (1) includes contemporaneous and lagged terms of world oil price $\left(\mathrm{OP}_{t}\right)$ in daily frequency and lagged terms of macroeconomic variables in lower frequency.

$$
Y_{t}=\alpha+\left(\sum_{\pi=0}^{k} \lambda_{t} L_{\mathrm{HF}}^{\pi} \mathrm{OP}_{t}\right)+\sum_{i=1}^{q} \gamma_{i} L^{i} Y_{t}+\varepsilon_{t}
$$

where $L_{\mathrm{HF}}$ and $L$ are lag operators of high-frequency variable (world oil price) and lowfrequency variables (macroeconomic variables) respectively; $\gamma_{i}$ are coefficients of lagged macroeconomic variables; $\lambda_{t}$ are coefficients of contemporaneous and lagged world oil price reflecting the impact of world oil price on macroeconomic variables.

Following Mork (1989), Cuñado and De Gracia (2005), Köse and Baimaganbetov (2015), Artami and Hara (2018), we decompose changes in world oil price into positive changes $\left(\mathrm{OPP}_{t}\right)$ and negative changes $\left(\mathrm{OPN}_{t}\right)$ to investigate the asymmetric impact:

$$
\begin{aligned}
& \mathrm{OPP}_{t}=\max \left\{\ln \left(\mathrm{OP}_{t}\right)-\ln \left(\mathrm{OP}_{t-1}\right), 0\right\} \\
& \mathrm{OPN}_{t}=\min \left\{\ln \left(\mathrm{OP}_{t}\right)-\ln \left(\mathrm{OP}_{t-1}\right), 0\right\}
\end{aligned}
$$

Replacing $\mathrm{OP}_{t}$ in the model (1) by $\mathrm{OPP}_{t}$ and $\mathrm{OPN}_{t}$, we get a non-linear model:

$$
Y_{t}=\alpha+\left(\sum_{\pi=0}^{k} \lambda_{t}^{\mathrm{OPP}} L_{\mathrm{HF}}^{\tau} \mathrm{OPP}_{t}\right)+\left(\sum_{\pi=0}^{k} \lambda_{t}^{\mathrm{OPN}} L_{\mathrm{HF}}^{\tau} \mathrm{OPN}_{t}\right)+\sum_{i=1}^{q} \gamma_{i} L^{i} Y_{t}+\varepsilon_{t}
$$

In model (4), $\lambda_{t}^{\mathrm{OPP}}$ and $\lambda_{t}^{\mathrm{OPN}}$ respectively reflect the impact of positive and negative changes in world oil price on macroeconomic variables. $\lambda_{t}^{\mathrm{OPP}}$ and $\lambda_{t}^{\mathrm{OPN}}$ are expected to have positive signs $(>0)$ in models of domestic oil price and inflation. This expectation implies a positive change in world oil price raises domestic oil price and inflation rate; conversely, a negative change in world oil price causes domestic oil price and inflation rate to reduce. However, $\lambda_{t}^{\mathrm{OPP}}$ and $\lambda_{t}^{\mathrm{OPN}}$ are expected to have negative signs $(<0)$ in the model of output growth, reflecting a positive change in world oil price deteriorates output growth and a negative change in world oil price boosts output growth in reverse. The impacts of OPP and OPN are asymmetric when their impact magnitudes are significantly different, i.e. $\left(\left|\lambda_{t}^{\mathrm{OPP}}\right| \neq\left|\lambda_{t}^{\mathrm{OPN}}\right|\right)$. In addition, when the significant lagged impacts of OPP and OPN are not similar in lag periods, the responses of 
macroeconomic variables to positive and negative changes in the world oil price are also asymmetric in timing.

As the world oil price is high-frequency variable, numbers of slope parameters relative to OPP and OPN would become very large $\left\{\lambda_{\tau}^{\mathrm{OPP}}, \lambda_{\tau}^{\mathrm{OPN}}\right\}_{\tau=0}^{k}$ when the number of lags $(k)$ increases. To reduce slope parameters, the study follows Ghysels et al. (2006) and Ghysels et al. (2007) to use a normalized beta weighting function. Thus, model (4) is rewritten as follows:

$$
\begin{aligned}
& Y_{t}=\alpha+\sum_{\tau=0}^{k-1} \mathrm{OPP}_{t-\tau}\left(\frac{\omega_{\tau}^{\theta_{1}^{\mathrm{OPP}}-1}\left(1-\omega_{\tau}^{\theta_{2}^{\mathrm{OPP}}-1}\right)}{\sum_{j=0}^{k} \omega_{j}^{\theta_{1}^{\mathrm{OPP}}-1}\left(1-\omega_{\tau}^{\theta_{2}^{\mathrm{OPP}}-1}\right)}+\theta_{3}^{\mathrm{OPP}}\right) \lambda^{\mathrm{OPP}} \\
& +\sum_{\pi=0}^{k-1} \mathrm{OPN}_{t-\pi}\left(\frac{\omega_{\tau}^{\theta_{1}^{\mathrm{OPN}}-1}\left(1-\omega_{\tau}^{\theta_{2}^{\mathrm{OPN}}-1}\right)}{\sum_{j=0}^{k} \omega_{j}^{\theta_{1}^{\mathrm{OPN}}-1}\left(1-\omega_{\tau}^{\theta_{2}^{\mathrm{OPN}}-1}\right)}+\theta_{3}^{\mathrm{OPN}}\right) \lambda^{\mathrm{OPN}}+\sum_{l=1}^{q} \gamma_{l} L^{l} Y_{t}+\varepsilon_{t}
\end{aligned}
$$

where $k$ is the maximum number of lags, $\lambda_{t}^{\mathrm{OPP}}$ và $\lambda_{t}^{\mathrm{OPN}}$ are corresponding slope coefficients of OPP and OPN that are common across all lags. All actual lag coefficients, i.e. $\left\{\lambda_{\tau}^{\mathrm{OPP}}, \lambda_{\tau}^{\mathrm{OPN}}\right\}_{\tau=0}^{k}$, are obtained by applying weights to the estimated $\lambda_{t}^{\mathrm{OPP}}$ and $\lambda_{t}^{\mathrm{OPN}}$ and $\omega_{i}$, which is defined as follows:

$$
\omega_{i}= \begin{cases}\delta & i=0 \\ i /(k-1) & i=1,2, \ldots, k-2 \\ (1-\delta) & i=k-2\end{cases}
$$

where $\delta$ is a conventionally very small number $\delta=2.22 \mathrm{e}^{-16}$.

Following Ghysels et al. (2007), we impose some restrictions on these parameters to achieve convergence in the estimation process which involves the optimization of a highly non-linear objective function. First, optimal lag length of high-frequency variable is selected by Schwarz selection criterion with maximum lag lengths to vary from 20 days to 90 days (3 months). Second, there are zero weights at the high-frequency lag endpoint, $\theta_{3}=0$. Third, lags of low-frequency variables are set to be two in all models as lags higher than two are usually insignificant. The robustness test is performed by replacing world oil price in daily frequency by itself in weekly frequency.

\subsection{Variable and data description}

Period for research is after the 2008 crisis, specifically from January 2009 to March 2018. Measurements and frequencies of variables for estimation are showed in Table 1. Data were collected from four sources. World oil price is proxied by price of Brent crude oil from Federal Reserve Economic Data (FRED, 2019). Gross domestic product used for calculating output growth is from General Statistics Office of Vietnam (GSO, 2019). CPI used for calculating inflation rate is from International Financial Statistics (IFS, 2019). Domestic oil price is proxied by retail diesel price of Vietnam National Petroleum Group (Petrolimex, 2018) as diesel is the most consumed petroleum product in Vietnam according to data of International Energy Agency (IEA, 2019).

\section{A summary of oil market in Vietnam}

The status of oil imports and exports of Vietnam has changed significantly since 2009. Vietnam exports and imports various oil products, in which crude oil accounts for the largest 
JED

22,2

316

Variable description

part of oil exports while refined oil products are mainly imported. Although the value of crude oil is not as high as that of refined products, Vietnam has been a net oil exporter for many years. However, Vietnam has officially become a net oil importer since 2010 with difference between oil exports and imports becoming larger and larger (Figure 1). Moreover, Vietnam has also begun to import crude oil since 2010, which had never been seen before. These changes on the one hand show a large dependence of the economy on oil energy, on the other hand, imply the economy's ability to self-satisfy is gradually decreasing as domestic demand is increasing.

Regarding market structure, among 37 oil companies, Petrolimex dominates and holds more than $50 \%$ of the market share. This figure implies that the oil industry in Vietnam is relatively less competitive.

Prices of petroleum products are controlled strictly by the government. Retail prices are set based on the prime price, which is determined as the import price plus $(+)$ taxes and charges (import tax, excise tax, value added tax, environmental protection tax) plus $(+)$ business expense norm plus $(+)$ pre-tax profit norm plus $(+)$ petroleum price stabilization fund's (PPSF) contribution. The PPSF is formed from a specific and fixed amount and is identified as a cost item in the fuel price composition (Figure 2). When the prime price is considerably higher than the current retail price, the PPSF is used to limit the impact of increasing world oil price on domestic price, contributing to inflation control (see Figure 3).

In 2014, the Decree 83/2014/ND-CP was issued to replace the Decree 84/2009/ND-CP. Changes in regulation are considered as the government's effort to enhance competitiveness

\begin{tabular}{llll}
\hline Variable & Frequency & Calculation & Source \\
\hline Output growth $\left(\mathrm{GDP}_{t}\right)$ & Quarterly & $\ln \left(\mathrm{GDP}_{t}\right)-\ln \left(\mathrm{GDP}_{t-1}\right)$ & GSO $(2019)$ \\
Inflation $\left(\mathrm{INF}_{t}\right)$ & Monthly & $\ln \left(\mathrm{CPI}_{t}\right)-\ln \left(\mathrm{CPI}_{t-1}\right)$ & IFS $(2019)$ \\
Domestic oil price change $\left(\mathrm{VOP}_{t}\right)$ & Monthly & $\ln \left(\mathrm{VPP}_{t}\right)-\ln \left(\mathrm{VOP}_{t-1}\right)$ & Petrolimex $(2018)$ \\
Positive change in world oil price $\left(\mathrm{OPP}_{t}\right)$ & Daily & $\max \left\{\ln \left(\mathrm{OP}_{t}\right)-\ln \left(\mathrm{OP}_{t-1}\right), 0\right\}$ & FRED (2019) \\
Negative change in world oil price $\left(\mathrm{OPN}_{t}\right)$ & Daily & $\min \left\{\ln \left(\mathrm{OP}_{t}\right)-\ln \left(\mathrm{OP}_{t-1}\right), 0\right\}$ & FRED $(2019)$ \\
Source(s): Authors & & &
\end{tabular}

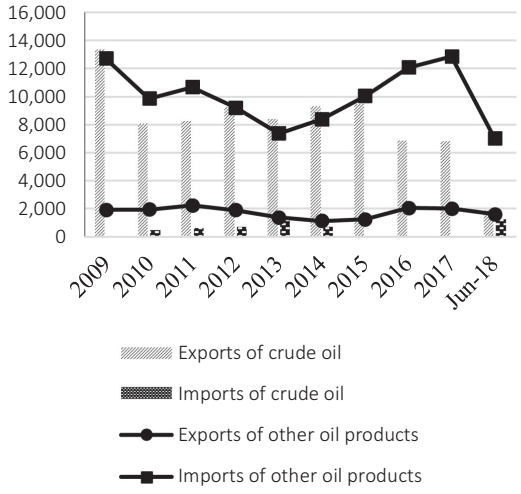

Quantity of oil imports and exports (1000 tons)

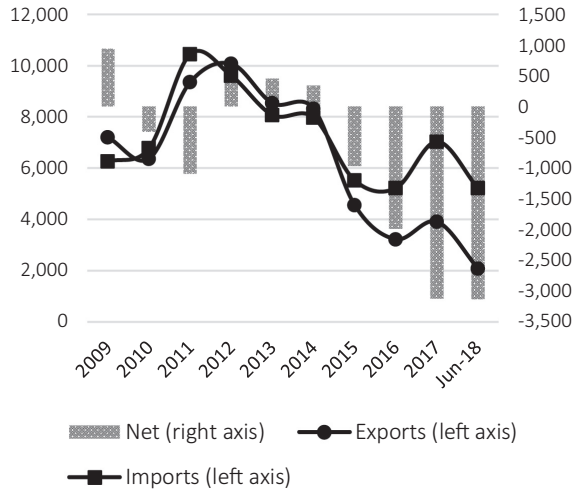

Value of oil imports and exports (million USD)
Figure 1. oil in Vietnam
Source(s): GSO (2019) 


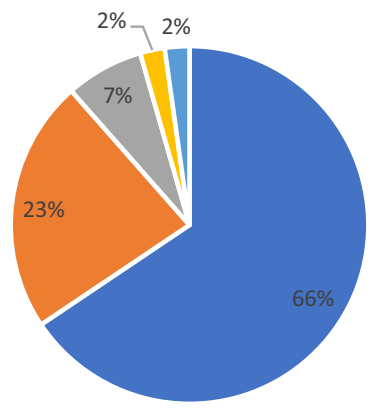

\section{MIDAS \\ approach to impact of world oil price}

- Import price

- Taxes and charges

- Business expense norm

- Pre-tax profit norm

- Stabilization fund

Note(s): Price composition for one litre of Diesel $0.05 \mathrm{~S}$ as of 05/06/2017

Source(s): Ministry of Finance (2019)

Figure 2.

Fuel price composition

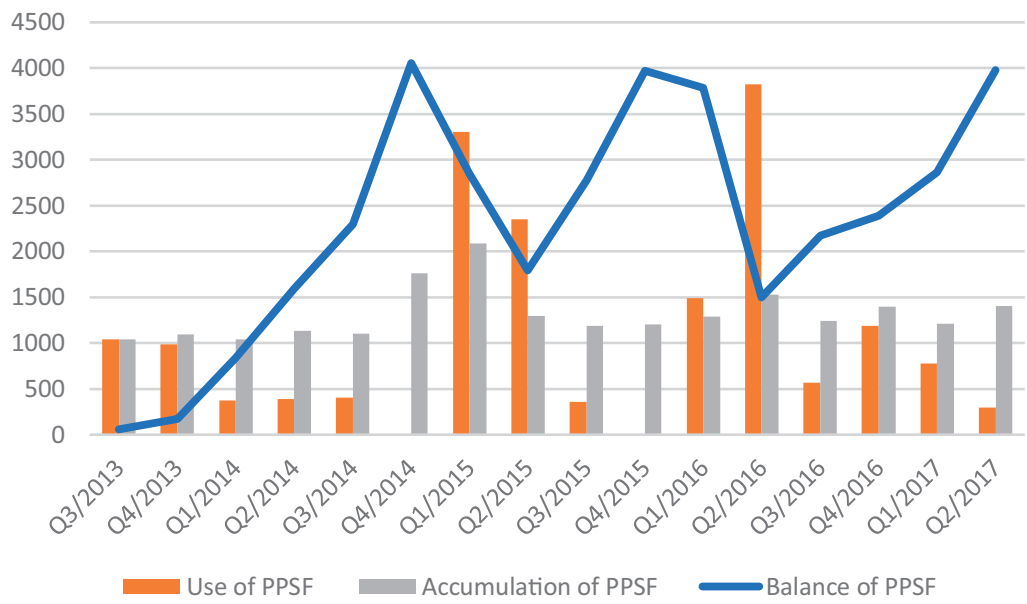

Source(s): Ministry of Finance (2019)

Figure 3. Petroleum price stabilization fund

and ensure domestic prices reflect fluctuations of world prices more promptly than before. Since 2014, the prime price has been estimated based on database of world price of 15 days closest to the calculation date while this figure in the period 2009-2014 was 30 days. The time between two consecutive times of price adjustment is minimum of 15 days for price increase, maximum of 15 days for price decrease. In terms of price adjustment, if the current prime price is lower than the previous one, principal traders can decrease the selling price regardless the margins of adjustment. Meanwhile, when the current prime price is higher than the previous one, principal traders can only actively increase the selling price if the increase is less than $3 \%$. In case of a rising of more than $3 \%$, they have to wait for the government's approval before adjusting prices. 
JED

22,2

318

\section{Estimation results and discussions}

Figure 4 shows the movements of the world and domestic oil prices in the studied period, which could be divided into four sub-periods. World oil price surges from 2009 to mid-April 2011, then fluctuates around 100 USD/barrel to June 2014. World oil price declines sharply until mid-January 2016 then keeps upward movement to March 2018. Although domestic oil price is under the strict control of the government, its changes are highly correlated to those of world oil price in the long term. However, fluctuations in domestic oil price could not catch up with those of world oil price in the short run. In particular, domestic oil price hardly changes before 2014; for example, world oil price fluctuates dramatically with an upward trend in 2010 while domestic oil price changes only four times during the year. Domestic oil price is changed more frequently after 2014 thanks to which it fluctuates closely to the world oil price. That adjustment frequency of the government on oil price has become more usual from 2014 is the reason for higher flexibility of domestic oil price. Relying on the prime price announced by the government, Petrolimex usually announces price adjustment twice times a month, the first time in some early days (between third and fifth) and the second time in some last days (between 19th and 20th). One of the reasons for the higher frequency of oil price adjustment is that the PPSF has less supporting source as Vietnam has been no longer a net oil exporter since 2011.

Figure 5 shows correlations between the change in world oil price and output growth, inflation. World oil price change is negatively correlated to output growth while positively correlated to inflation, implying a decrease in output growth and an increase in inflation following an oil price rise.

Stationarity of variables is tested by PP and KPSS and summarized in Table 2. According to PP test, only GDP is stationary at 5 significant level, the others are stationary at 1 significant level. KPSS test also could not reject the null hypothesis of stationary in any case. Therefore, all variables are appropriate for MIDAS estimation with beta weights.

Table 3 summarizes results of the model (4) by MIDAS estimation with beta weight. Columns 2, 4 and 6 show impact of OPP and OPN in daily frequency on domestic oil price, inflation and output growth respectively; columns 3,5 and 7 are corresponding results of OPP and OPN in weekly frequency. As the results of MIDAS estimation with OPP and OPN in

Figure 4.

Movements of the world and domestic oil prices

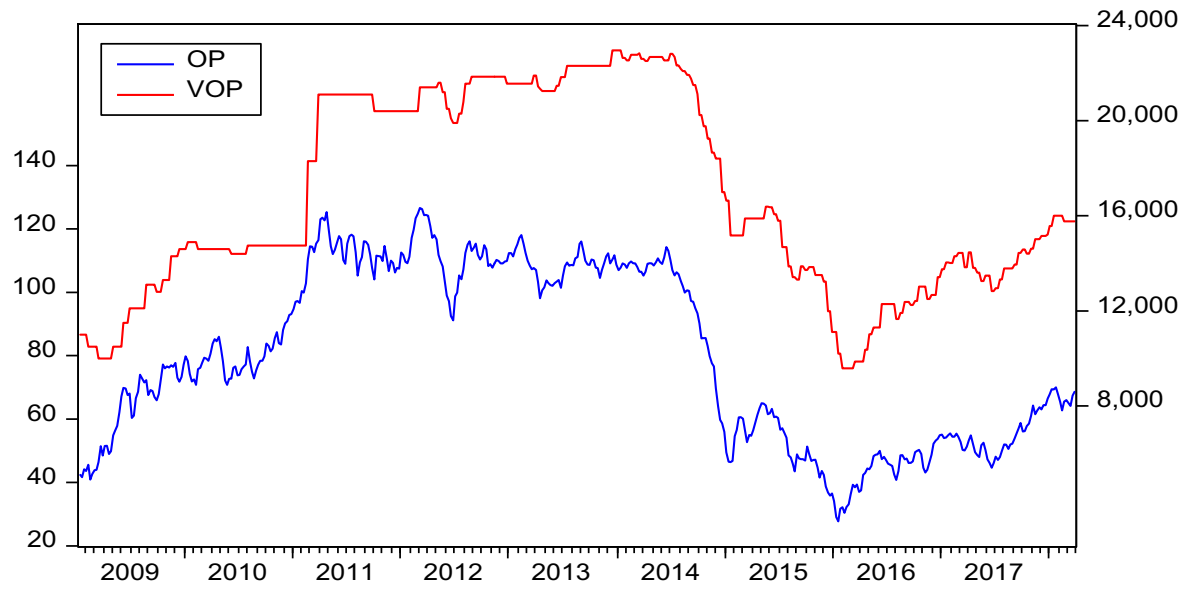

Source(s): Petrolimex and FRED (2019) 

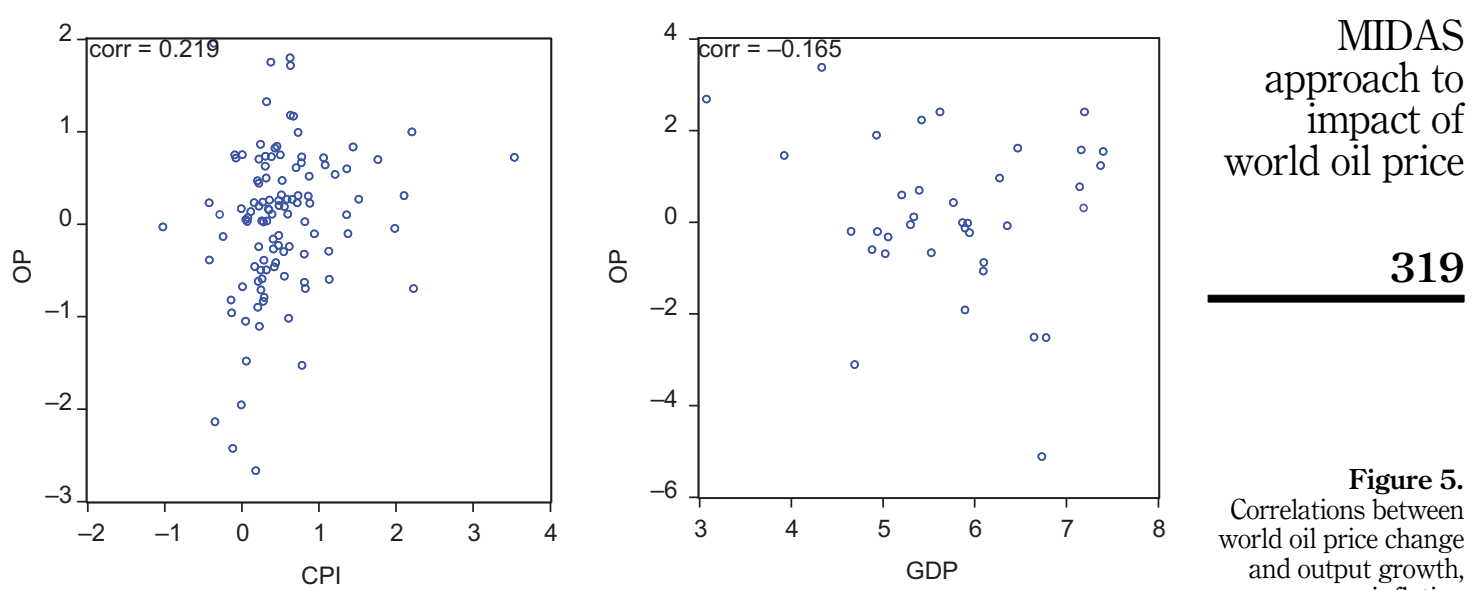

Source(s): Authors

Figure 5.

Correlations between world oil price change and output growth, inflation

\begin{tabular}{llcr}
\hline Series & Frequency & PP & KPSS \\
\hline GDP & Quarterly & $-3.206^{* * *}$ & 0.344 \\
INF & Monthly & $-5.392^{* * * *}$ & 0.263 \\
VOP & Monthly & $-6.565^{* * *}$ & 0.290 \\
OPP & Daily & $-46.072^{* * *}$ & 0.234 \\
OPN & Daily & $-45.863^{* * *}$ & 0.271
\end{tabular}

Note(s): ***, ** denotes significant level at $1 \%$ and $5 \%$ respectively

Table 2.

Source(s): Authors

Results of unit root test by $\mathrm{PP}$ và KPSS

\begin{tabular}{|c|c|c|c|c|c|c|}
\hline \multirow{2}{*}{$\begin{array}{l}\text { Variable } \\
\text { (1) }\end{array}$} & \multicolumn{2}{|c|}{ Domestic oil price model } & \multicolumn{2}{|c|}{ Inflation model } & \multicolumn{2}{|c|}{ Output growth model } \\
\hline & & & (4) & $(5)$ & & $(7)$ \\
\hline C & -0.001 & 0.001 & $0.001^{* * * *}$ & $0.002^{* *}$ & -0.044 & $0.015^{*}$ \\
\hline $\operatorname{GDP}(-1)$ & & & & & 2.233 & $0.846^{*}$ \\
\hline $\mathrm{GDP}(-2)$ & & & & & -0.420 & -0.179 \\
\hline $\mathrm{CPI}(-1)$ & & & $0.554 * * *$ & $0.451 * * *$ & & \\
\hline CPI $(-2)$ & & & -0.039 & $0.190 * *$ & & \\
\hline VOP(-1) & $0.574 * * *$ & $0.068^{* *}$ & & & & \\
\hline $\mathrm{VOP}(-2)$ & 0.004 & -0.032 & & & & \\
\hline $\mathrm{OPP} \lambda^{\mathrm{OPP}}$ & $6.564 * * *$ & $2.651 * * *$ & $0.373^{* *}$ & $0.073^{* *}$ & -2.333 & $0.190 *$ \\
\hline$\theta_{1}^{\mathrm{OPP}}$ & $3.893^{* *}$ & $0.982^{* * * *}$ & $8.551 * * *$ & $17.323^{* * * *}$ & $0.947 * * *$ & 0.156 \\
\hline$\theta_{2}^{\mathrm{OPP}}$ & $1.004^{* * * *}$ & $0.981 * * *$ & $1.024 * * *$ & $19.998 * * *$ & $0.981 * * *$ & 1.170 \\
\hline $\mathrm{OPN} \lambda^{\mathrm{OPN}}$ & $6.001^{* * * *}$ & $2.361 * * *$ & $0.364 * *$ & $0.133^{* *}$ & -1.496 & $-0.211 * *$ \\
\hline$\theta_{1}^{\mathrm{OPN}}$ & $1.627^{*}$ & $3.545^{* * * *}$ & $3.434^{*}$ & $0.975^{* * * *}$ & $0.965^{* * *}$ & $0.969 *$ \\
\hline$\theta_{2}^{\mathrm{OPN}}$ & $0.989 * * *$ & $5.723^{* * * *}$ & $12.199 *$ & $1.013 * * *$ & $0.974 * * *$ & $0.941 *$ \\
\hline Adj. $R^{2}$ & 0.721 & 0.608 & 0.800 & 0.475 & 0.823 & 0.700 \\
\hline
\end{tabular}

Note(s): ***, ** and $*$ denote significant level at $1 \%, 5 \%$ and $10 \%$ respectively Source(s): Authors

Table 3.

Estimation results on impact of world oil price on macroeconomic variables 
JED

22,2

320

daily and weekly frequency are consistent, the robustness of model is guaranteed. Therefore, we focus on the results generated by daily oil price for analysis.

Impacts of world oil price changes on domestic oil price are presented in Column 2 in Table 3. A change in world oil price causes the domestic oil price to change in the same direction as common coefficients $(\lambda)$ of OPP and OPN are significantly positive as expected. In terms of magnitude, a positive oil price change causes a stronger impact than a negative oil price change does. This result implies the asymmetric impact of world oil price on the domestic oil price. In the circumstance that retail domestic oil prices are determined by petroleum sellers and domestic petroleum prices are controlled by the government, this asymmetric impact implies different adjustments on domestic oil price of authorities and also petroleum sellers when the world oil price changes. Particularly, the size of domestic oil price adjustment following a positive change in world oil price is larger than the size of domestic oil price adjustment following a negative change in world oil price. Price adjustment behaviour of oil sellers can explain for this asymmetry. When there is an increase in world oil price, domestic oil sellers will make a corresponding positive adjustment on domestic oil price due to afraid of profit decline. This adjustment can also be accepted easily by public as Vietnam is a net oil importer. However, when world oil price decreases, domestic oil sellers usually hesitate to determine a corresponding negative adjustment on domestic oil price because this adjustment will lead to revenue reduction.

Both $\theta_{1}$ and $\theta_{2}$ of OPP and OPN are significantly positive $(>0)$, thus, actual lagged coefficients of OPP and OPN can be obtained. Figure 6 indicates world oil price influences on domestic oil price within 25 days, which is consistent with price adjustment frequency of authorities. The lagged patterns for coefficients of OPP and OPN are different, reflecting asymmetry. In terms of magnitude, the peak of the former is higher than that of the latter, implying impact of a positive change in world oil price on domestic price is more powerful than that of a negative change in world price on domestic price. In terms of response timing, domestic oil price responds to negative change in world oil price more quickly. In particular, when the world oil price rises, domestic oil price increases significantly from the 12th day and reach the maximum level on the 23rd day. When world oil price decreases, domestic oil price

Figure 6.

The lagged patterns for coefficients of OPP and OPN in the domestic oil price model

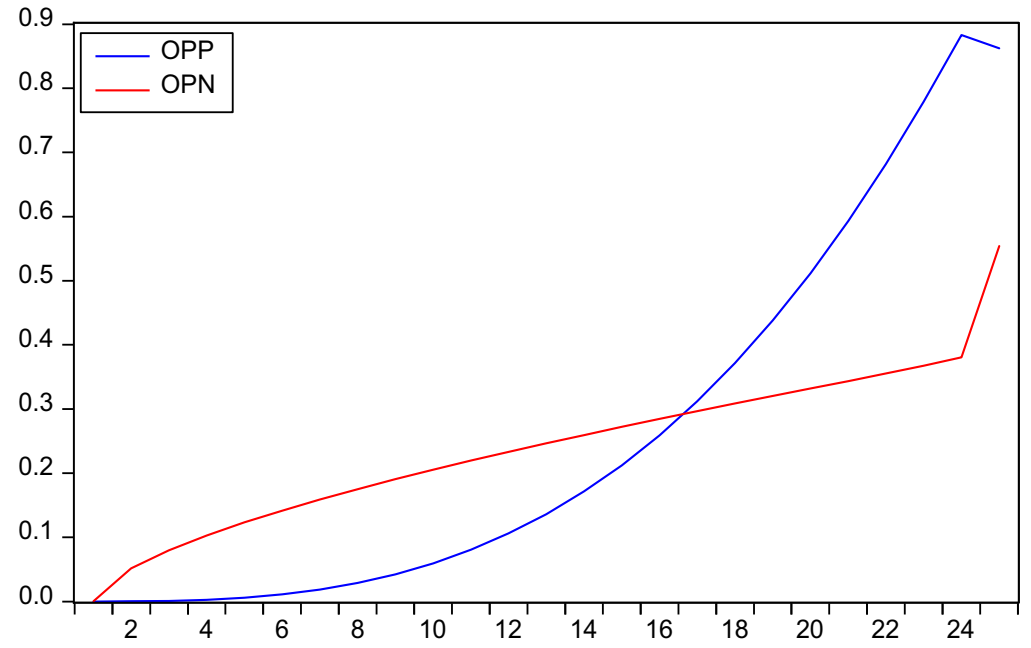

Source(s): Authors 
declines immediately at a limited degree. The highest decline is reached on the 25 th day after. Different responses in terms of timing of OPP and OPN reflect the viewpoint of government on oil price control. The authorities usually postpone the pass-through of positive change in the world oil price to domestic oil price because of inflation pressure effect. Meanwhile, a downward movement of world oil price is transmitted quickly to domestic oil price for the purpose of releasing inflation pressure.

Results of the MIDAS estimation of inflation model summarized in column 4 in Table 3. Common coefficients of OPP and OPN are positive at 5\% significant level, indicating the changes of world oil price influences on domestic inflation as expected. A positive change in the world oil price causes the domestic inflation to rise and a negative change in world oil price leads to decrease in inflation. Compared to the impact of negative change in oil price on inflation, that is positive change in oil price on inflation is also stronger, implying asymmetric impact. This result is appropriate and consistent with asymmetric adjustment on domestic oil price by authorities following a change in world oil price as analysed above. In addition, $\theta_{1}$ and $\theta_{2}$ are also significantly positive, confirming the lag impact of world oil price on inflation.

Figure 7 shows the asymmetric impact of positive and negative changes in world oil price on inflation in detail. Following a positive change in world oil price, the domestic price goes up since the 16th day and reach the highest level at the 20 th day. The reason for the delayed influence of world oil price on inflation is the late adjustment of authorities on the domestic oil price. Meanwhile, domestic inflation decreases within 15 days following a negative change in world oil price thanks to quick oil price adjustment of authorities.

Column 6 in Table 3 summarizes the results of MIDAS model for output growth. Although $\theta_{1}$ and $\theta_{2}$ are significantly positive, common coefficients of OPP and OPN are insignificantly negative. Thus, the short-run impact of world oil price on domestic output growth could not be confirmed. Studies by Olomola and Adejumo (2006), Trang and Hong (2016) also find no significant impact of world oil price on domestic output growth in Nigeria and Vietnam respectively. As oil is necessary input for production, changes in oil price cause a negligible impact on the planned production process in the short run. However, oil price changes can have a long-run causal relationship with output growth because price changes can influence

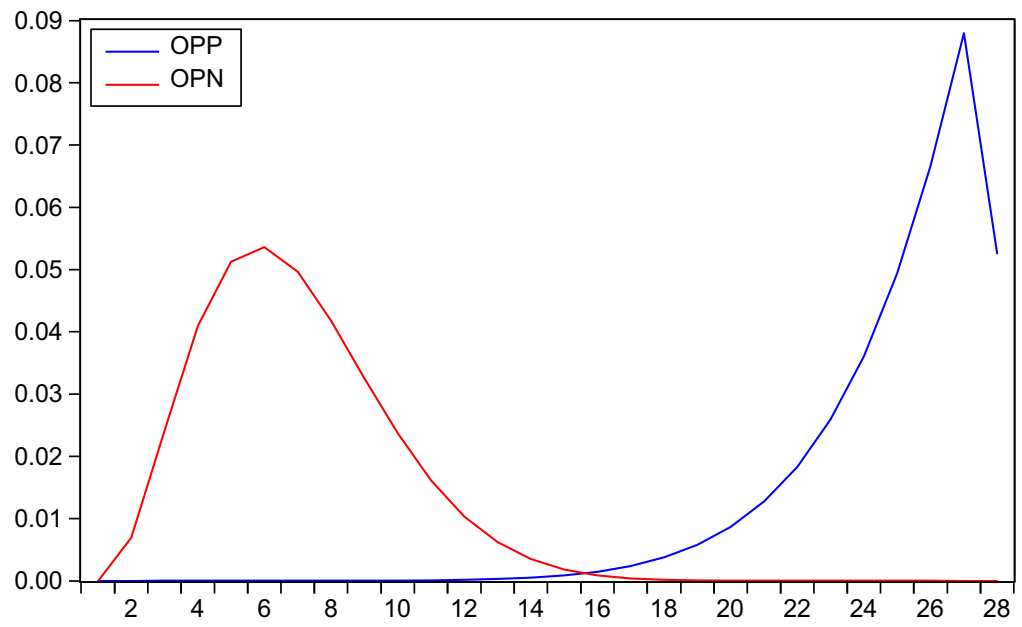

Source(s): Authors

Figure 7.

The lagged patterns for coefficients of OPP and $\mathrm{OPN}$ in the inflation model 
on demand for goods, which affects output as a result. For example, Trung and Vinh (2011) find a long-run relationship between oil price and output in Vietnam.

\section{Conclusions and policy recommendations}

This study investigates the asymmetric impact of world oil price in high-frequency data on low-frequency data of domestic oil price, inflation and output growth in Vietnam after the global financial crisis. Employing MIDAS estimation with beta weight method, the study finds three main results.

First, changes in world oil price cause a significantly powerful impact on domestic oil price and inflation. This impact is unavoidable as Vietnam is an oil importer and has become a net oil importer since 2010.

Second, the impact of world oil price on domestic oil price and inflation is asymmetric in terms of magnitude and timing. A positive change in world oil price causes a stronger impact in terms of magnitude than a negative change in world oil price does. This phenomenon can be explained by the price-adjustment behaviour of domestic oil sellers. In terms of timing, the impact of a positive change in world oil price is postponed in 25 days while that of a negative change in world oil price occurs immediately. Government control on domestic oil price for the purpose of mitigating inflation pressure is the reason behind this timing asymmetry.

Third, there is no statistically significant evidence on the short-run causal relationship between world oil price and domestic output growth. As oil and petroleum products are necessary inputs for production processes, oil demand elasticity to price could be low in the short run.

Conclusions generated by this study confirm the responses of domestic oil price to positive and negative changes in world oil price are not the same in magnitude. The question of whether domestic oil distributors make less decrease in retail oil price following a corresponding negative change in the world oil price for the purpose of getting more profit could be raised. Authorities should have an official investigation on this issue to protect the rights of consumers and entities using petroleum products as input. Besides, as an increase in world oil price harms the economy, the government should diminish dependency on petroleum products by increasing power usage effectiveness on the one hand and developing alternative energy.

\section{References}

Artami, R.J. and Hara, Y. (2018), "The asymmetric effects of oil price changes on the economic activities in Indonesia”, Jurnal Ilmu Ekonomi, Vol. 7 No. 1, pp. 59-76.

Barro, R.J. (1984), Macroeconomics, John Wiley and Sons, New York, NY.

Başkaya, Y.S., Hülagü, T. and Küçük, H. (2013), "Oil price uncertainty in a small open economy”, IMF Economic Review, Vol. 6, pp. 168-198.

Bernanke, B.S. (1983), "Irreversibility, uncertainty, and cyclical investment", Quarterly Journal of Economics, Vol. 98 No. 1, pp. 85-106.

Bernanke, B., Gertler, M. and Watson, M. (1997), "Systematic monetary policy and the effect of oil price shocks", Brookings Papers on Economic Activity, Vol. 1, pp. 91-142.

Bresnahan, T.F. and Ramey, V.A. (1993), "Segment shifts and capacity utilization in the U.S. automobile industry", American Economic Review Papers and Proceedings, Vol. 83 No. 2, pp. 3213-218.

Brown, S.P.A. and Yücel, M.K. (1999), "Oil prices, and US aggregate economic activity: a question of neutrality”, Economic and Financial Policy Review, Federal Reserve Bank of Dallas, Vol. 2, pp. 16-23. 
Burbidge, J. and Harrison, A. (1984), "Testing for the effects of oil-price rises using vector autoregressions”, International Economic Review, Vol. 25 No. 2, pp. 459-484.

Cuñado, J. and De Gracia, F.P. (2005), "Oil prices, economic activity and inflation: evidence for some Asian countries", Quarterly Review of Economics and Finance, Vol. 45 No. 1, pp. 65-83.

Darby, M. (1982), "The price of oil and world inflation and recession", American Economic Review, Vol. 72, pp. 738-751.

Davies, S.J. (1987), "Allocative disturbances and specific capital in real business cycle theories", American Economic Review, Vol. 77 No. 2, pp. 326-332.

Davies, S.J. and Haltiwanger, J. (2001), "Sectoral job creation and destruction responses to oil price changes", Journal of Monetary Economics, Vol. 48 No. 3, pp. 465-512.

Ebrahim, Z., Inderwildi, O.R. and King, D.A. (2014), "Macroeconomic impacts of oil price volatility: mitigation and resilience", Frontiers in Energy, Vol. 8, pp. 9-24.

Federal Reserve Economic Data (2019), "Economic data", available at: https://www.stlouisfed.org (accessed 5 August 2019).

General Statistics Office of Vietnam (2019), "Online database”, available at: http://www.gso.gov.vn (accessed 5 August 2019).

Ghysels, E., Santa-Clara, P. and Valkanov, R. (2006), "Predicting volatility: getting the most out of return data sampled at different frequencies", Journal of Econometrics, Vol. 131, pp. 59-95.

Ghysels, G., Sinko, A. and Valkanov, R. (2007), "MIDAS regressions: further results and new directions", Econometric Reviews, Vol. 26, pp. 53-90.

Gisser, M. and Goodwin, T. (1986), "Crude oil and the macroeconomy: tests of some popular notions", Journal of Money, Credit and Banking, Vol. 18, pp. 95-103.

Hamilton, J.D. (1983), "Oil and the macroeconomy since world war II", Journal of Political Economy, Vol. 91 , pp. 228-248.

Hamilton, J.D. (1988), “A neoclassical model of unemployment and the business cycle”, Journal of Political Economy, Vol. 96 No. 3, pp. 593-617.

Hamilton, J.D. (1996), “This is what happened to the oil price-macroeconomy relationship”, Journal of Monetary Economics, Vol. 38, pp. 215-220.

Hamilton, J.D. (2009), “Understanding crude oil prices”, Energy Journal, Vol. 30, pp. 179-206.

International Energy Agency (2019), "Data and statistics", available at: http://www.iea.org/data-andstatistics (accessed 5 August 2019).

International Financial Statistics (2019), "IMF data access to macroeconomics and financial data", available at: http://www.data.imf.org (accessed 5 August 2019).

Kilian, L. (2009), "Not all oil price shocks are alike: disentangling demand and supply shocks in the crude oil market", American Economic Review, Vol. 99 No. 3, pp. 1053-1069.

Köse, N. and Baimaganbetov, S. (2015), "The asymmetric impact of oil price shocks on Kazakhstan macroeconomic dynamics: a structural vector autoregression approach", International Journal of Energy Economics and Policy, Vol. 5 No. 4, pp. 1058-1064.

Lee, K., Ni, S. and Ratti, R. (1995), "Oil shocks and the macroeconomy: the role of price variability", Energy Journal, Vol. 16, pp. 39-56.

Long, S. and Liang, J. (2018), "Asymmetric and nonlinear pass-through of global crude oil price to China's PPI and CPI inflation”, Economic Research-Ekonomska Istraživanja, Vol. 31 No. 1, pp. 240-251.

Luiggi, D. and Neil, A.T. (2016), "The asymmetric effects of oil price shocks on the Canadian economy international", Journal of Energy Economics and Policy, Vol. 6 No. 2, pp. 167-182.

Ministry of Finance (2019), Oil and Gasoline Prices, available at: http://www.mof.gov.vn (accessed 5 August 2019). 
JED

22,2

324

Mork, K.A. (1989), "Oil and macroeconomy when prices go up and down: an extension of Hamilton's results", Journal of Political Economy, Vol. 97 No. 3, pp. 740-744.

Olomola, P.A. and Adejumo, A.V. (2006), "Oil price shock and macroeconomic activities in Nigeria", International Research Journal of Finance and Economics, Vol. 3, pp. 29-35.

Petrolimex (2018), Oil and Gasoline Prices, available at: http://www.petrolimex.com.vn (accessed 5 August 2019).

Pindyck, R.S. (1991), "Irreversibility, uncertainty, and investment", Journal of Economic Literature, Vol. 29, pp. 1110-1148.

Rasche, R.H. and Tatom, J.A. (1981), "Energy price shocks, aggregate supply and monetary policy: the theory and the international evidence", Carnegie-Rochester Conference Series on Public Policy, Vol. 14, pp. 9-93.

Thanh, N.D., Trinh, B. and Thang, D.N. (2009), "The impact of oil price increase: A preliminary quantitative analysis", Vietnam National University Journal of Science, Vol. 25, pp. 25-38 (in Vietnamese).

Trang, N.T.N. and Hong, D.T.T. (2016), "Non-linear impacts of oil price on growth, inflation, unemployment and fiscal deficit", Journal of Economic Development, Vol. 27 No. 6, pp. 23-44 (in Vietnamese).

Trung, L.V. and Vinh, N.T.T. (2011), "The impact of oil prices, real effective exchange rate and inflation on economic activity: novel evidence for Vietnam", Discussion Paper Series, Kobe University, Kobe.

Valcarcel, V.J. and Wohar, M. (2013), "Changes in the oil price-inflation pass-through", Journal of Economics and Business, Vol. 68, pp. 24-42.

\section{Corresponding author}

Trinh Thi Tuyet Pham can be contacted at: trinhptt@buh.edu.vn

For instructions on how to order reprints of this article, please visit our website:

www.emeraldgrouppublishing.com/licensing/reprints.htm

Or contact us for further details: permissions@emeraldinsight.com 